\title{
Participative Digital Photography to Evaluate the Transition to University
}

\author{
Silvia Sierra-Martínez \\ sierra@uvigo.es \\ Universidad de Vigo, Spain \\ María Esther Martínez-Figueira \\ esthermf@uvigo.es \\ Universidad de Vigo, Spain \\ Manuela Raposo-Rivas \\ mraposo@uvigo.es \\ Universidad de Vigo, Spain \\ Ángeles Parrilla \\ parrilla@uvigo.es \\ Universidad de Vigo, Spain
}

\begin{abstract}
The article shows the possibilities of textualized digital photography in different technological media as an innovative resource for evaluating the process of transitioning to university.

The use of photovoice as a methodological tool is explained and analyzed from a participative research perspective as one which invites participants to take on an active role in reflecting on and taking part in their new academic situation. 142 first-year students doing degrees in Pre-school and Primary Education at the University of Vigo participated in the Project; this has led to the creation of a total of 560 textualized photographs related to the topic of the study.

The results, based on a denotative analysis of the images and a connotative analysis of the texts produced by the students, identifies the spaces and situations in the university life of students which are essential, the role played by architectural elements and material resources, as well as the connection between their identity as students and the processes of university participation and management.

The conclusions show the suitability of visual technological resources for evaluating educational transitions, the ability of photovoice to encourage participants to reflect and engage in critical thought, and the need to recognize the students' voices and authority as soon as they enter university.
\end{abstract}

\section{Keywords}

Visual and narrative methodologies; Visual technological resources; Photovoice; Participative research; Transitioning to university 


\section{Introduction}

The first year of university plays an important role in the relationship the student establishes with their degree studies and their university experience. Universities should offer a transition process which connects with their expectations before they begin the new formative stage. It should awaken their interest and promote high standards of effort and commitment. Furthermore, this process promotes a personal experience which determines the performance and satisfaction of those beginning a university degree.

Nonetheless, the academic policy and management strategy normally found at universities is fundamentally based around institutional and academic contact with the new surroundings. To achieve this, actions such as events for new students and welcome days have been used. These have shown the need to address the transition to university from a more pedagogical and personal perspective (Corominas, 2001).

In this work, we will focus on the transition to university, analyzing the perception and personal vision which first-year students have upon arriving. To do so, we have proposed using a narrativevisual methodology known as photovoice (Doval, Martínez-Figueira \& Raposo, 2013; Melleiro \& Gualda, 2005; Wang, 2006; Wang \& Burris, 1997). It is an innovative proposal which gives voice to those traditionally not heard from (Wang, 1999, 2006) and which evaluates their needs, using digital photography. Furthermore, photovoice is clearly committed to change and social improvement.

The main point is to learn about and evaluate how the educational transition is felt, from Baccalaureate and vocational training to university education. To do so, it is important to adopt participative and innovative methods which go beyond the traditional ones, and which recognizes and values the opinions of new students.

\section{Theoretical framework}

\footnotetext{
"The first year (...) is an indicator of the quality of the education, of its competitiveness, and of its good state in the 21st century. Universities must be capable of honestly showing students the importance of their first year, and making as much effort as possible to make the transition experience successful" (Johnston, 2013, p.10).
}

The expansion of higher education and the incorporation into it of a growing number of ever more diverse individuals has given rise to new preoccupations and study topics, such as access to university (Figuera \& Coiduras, 2013). As a consequence, institutions must reconsider the role played by the first year of university and the support which students receive during this crucial period of their education. The transition which takes place between post-obligatory schooling and higher learning presents students with a twofold challenge. On one hand, it represents a break with the previous academic culture and the need to adapt to new rules while still being adolescents. On the other, it represents the need to adapt and adjust to a new academic institution which, in many cases, means being in a new location, adapting to a new academic culture, leaving familiar surroundings, and more. Faced with this, universities should offer students a first year in which their formal and informal learning experiences are viewed as a unique situation (Johnston, 2013).

Understanding these circumstances cannot be limited to institutional decisions, made without taking into account the interests of the users. Student voices, which are generally silenced by an entrenched culture which often does not recognize them as autonomous subjects with rights, must be taken into consideration (Gascón \& Godoy, 2015). Freire (1970) already criticized this situation in his Pedagogy of the Oppressed. Specifically, his theory of an antidialogical action refers to 
certain learned roles in which teacher's take on a dominant character, becoming the decision maker and exercising control over their students. This is the premise which the student-voice movement is against.

This movement has been conceptualized as each and every initiative whose implementation is based around increasing student decision-making with regards to the design, management, and evaluation of every aspect of academic life (Susinos, 2012). Just as Rudduck and Flutter (2007) have assured, we need to view students in another light, and abandon the adult-centric view of childhood and adolescence in order to thereby recognize students as interlocutors who have their own say in pedagogical matters. This means increasing their participation as a mobilizing element for change (Parrilla, Martínez-Figueira \& Zabalza, 2012). Nonetheless, said participation has been viewed by some authors as a relatively recent phenomenon for university students. As YañezUrbina, Figueroa, Soto \& Sciolla (2018) have shown, its origins can be traced back to the 60s and 70s; at that time, it gained ground, only to then lose it, with a resurgence occurring thanks to current participative methodologies.

One of the most innovative resources, within the university context, aimed at promoting participation and giving voice to students is photovoice. Photovoice is a part of visual methods which, as shown by Mannay (2017), have the potential to cause one to empathetically understand how others experience their worlds. Photovoice is conceived as a participative research-action methodology which, through the use of photographs and other resources produced by the participants, promotes the reflection on and improvement of issues pertaining to their own needs (Parrilla, Raposo-Rivas, Martínez-Figueira \& Doval, 2017). It has been used in very different fields for the students of very diverse topics, from Anthropology (Allen, 2012; Delgado, 2015; Johnson, 2011) to Health Sciences (Bukowski \& Buetow, 2011; Garner, 2014; Wang, 1999), and from Education (Doval, Martínez-Figueira \& Raposo, 2013; Kaplan \& Howes, 2004; Parrilla, et al., 2017; Nelson \& Christensen, 2009; Smith, Bratini \& Appio, 2012; Zenkov, \& Harmon, 2009) to the Arts (Edwards, Perry, Janzen \& Menzies, 2012).

Photovoice allows for a more organic understanding of the participants' world, which is studied from their perspective. This causes insights, key moments and situations which may appear invisible to those distant from the situation being analyzed, to occur (Parrilla, et al., 2017). This methodology is associated with processes with promote dialogue and the later transformation and improvement (Wang, 2006; Doval, Martínez-Figueira \& Raposo, 2013) of the situations studied. This way, students play a relevant role in the research, being co-researchers with regards to the analysis of the object of the study. It must be said that this empowerment of the role given to participants is one of the most polemical and contested from the point-of-view of traditional research (Novek \& Morris-Oswald, 2012; Prins, 2010).

As its name indicates, Photovoice is based on the user's 'voice' and 'photo' photography, the language of the fixed image. The use of this visual resource allows one to take advantage of the technological abilities of university students. With Photovoice, "Participants use cameras, tablets, smartphones... to record environments or situations and generate data, causing thought and debate, from their it is directly involved in the research process" (Parrilla, et al., 2017, p.19). University students have been born into a technological world, and as such are familiar with the use of AV and ICT technology. They are regularly known as 'digital natives', 'Generation NET', 'Generation Multimedia', 'Generation Digital', 'Generation Y', 'Millennials', and the like (Esteve, Duch \& Gisbert, 2014). Therefore, a priori, they find any activity incorporating technological resources to be attractive and motivating.

Likewise, the use technological resources for evaluation is becoming ever more common, both for the design and presentation of information and for the development and recording of results and responses. As pointed out by Redecker (2013), in has been used in traditional contexts to make the process and product more effective and efficient. They, without a doubt, "offer a promising way 
of evaluating the most complex dimensions and behavior" (p.12). The technological resources referred to by various authors often include computerized objective tests, computer-assisted evaluation, augmented reality, virtual worlds and immersive games (Redecker, 2013); electronic portfolios (Gallego-Arrufat \& Cebrián-de-la-Serna, 2018; Tur \& Urbina, 2014); electronic rubrics (Cebrián, Serrano \& Ruiz, 2014; Gallego-Arrufat \& Cebrián-de-la-Serna, 2018) and videoannotations (Gallego-Arrufat \& Cebrián-de-la-Serna, 2018). It does not occur in the same way with photography, which is considered to be a didactic resource (Cortés-Selva \& Wandosell-Fernández, 2018; Parrilla et al., 2017), but not as one for evaluation. As previously put forward, we have ventured to use the fixed image through photovoice in the research carried out in order to evaluate arriving at university from the perspective of students starting their journey into higher learning.

In short, Photovoice allows for a creative use of technology for research purposes and, in this case, for evaluating the experiences of first-year university students. The originality of this study can be seen via the following:

- The technology is not specifically meant for research and evaluation, photography in different media, but it is being used for this end.

- The participants themselves produce and collect information through photos and narratives which they freely take and write.

- It is a non-intrusive research process, thanks to the use of media which are completely incorporated into their lives as research tools.

- It allows for the creative use of textualized photos, both for presenting results and disseminating them.

- It enriches traditional 'evaluative' instruments and their common use. The technology is flexible and accessible to the participants, allowing them to create visual narrations and to promote reflection and evaluation.

For all of these reasons, Photovoice is the driving thread for giving voice to the students. Through it their vision of the university is explored and evaluated, and meanings and feelings they have regarding it are analyzed.

\section{Methodology}

This article is part of a Research and Innovation Project ${ }^{1}$ whose main objective is to learn about how students accessing university for the first time view it. Furthermore, it aims to offer an innovative analysis instrument for facilitating a participative evaluation of this new stage.

The project responds to an assumption of research as a process of change and improvement, interested not only in the results of the study being carried out, but in the research process itself as a mechanism and strategy for change. A participative design has been opted for, in which students become co-researchers; in other words, active members who participate in and are committed to a transition process which has been thought out and articulated for them and with them.

The general objectives of this project are:

- To explore the interpretation (meaning and feelings) that new students develop about the university institution.

\footnotetext{
1 "The transition to university via the visual narratives of new students. A pedagogical proposal for action and improvement". Dir. Ma Esther Martínez-Figueira (2016). Faculty of Education and Sports Sciences of the University of Vigo.
} 
- To detect participation needs within an institutional context.

- To promote knowledge of the faculty environment and space.

The aim is, in short, to explore and evaluate the image which newly-arrived university students have of the university in order to find key information to facilitate their incorporation and active participation in it.

\section{a. Institutional context}

The study has been carried out at a faculty of the University of Vigo, a young university which has been in existence for a little more than a quarter of a century. This faculty offers undergraduate degrees in Early-Childhood Education (EI in Spanish), Primary Education (EP in Spanish), and Physical Activity and Sports Sciences (CCAFD in Spanish). This offer is complemented by four Master's and three doctorate programs. The following table is a summary of their distinctive characteristics.

\begin{tabular}{|l|l|}
\hline $\begin{array}{l}\text { Degrees and } \\
\text { number of spaces } \\
\text { offered }\end{array}$ & \begin{tabular}{l}
\multicolumn{1}{c|}{ Faculty of Education and Sports Sciences } \\
(75) and Degree in Physical Activity and Sports Sciences (100).
\end{tabular} \\
\hline Ratio & $\begin{array}{l}116 \text {-member teaching and research staff, 6-member administrative and } \\
\text { services stuff, 406 EI students, 299 EP students, and 485 CCAFD } \\
\text { students. }\end{array}$ \\
\hline Spaces and \\
provision of \\
teaching-learning \\
infrastructure & $\begin{array}{l}\text { Classrooms of different sizes (small, medium, and large) with } \\
\text { technological material, normally used for master classes and exams. } \\
\text { Classroom-labs with specific technological and teaching resources, } \\
\text { normally used for theoretical-practical activities (New-technology and IT } \\
\text { lab, Visual-arts teaching lab, etc.). } \\
\text { Sports-training rooms with relevant resources: gym, tatami, track-and- } \\
\text { field track, sports center, climbing wall, pool, synthetic-grass football } \\
\text { pitch, weight room, and dock for watercraft. } \\
\text { University library: located in the campus' central building, 100 meters } \\
\text { from the faculty. } \\
\text { Other infrastructure: teachers' offices, seminar rooms, student-delegation } \\
\text { rooms, and administrative rooms. }\end{array}$ \\
\hline General services & $\begin{array}{l}\text { At the faculty itself: Photocopying service (photocopiers freely available } \\
\text { with the use a photocopying card) and food and beverage service (coffee, } \\
\text { drink, and food machines for the entire community). } \\
\text { Away from the faculty: There is a photocopying company and a café with } \\
\text { food 100 meters from the campus' central building. }\end{array}$ \\
\hline
\end{tabular}

Table 1. Distinctive characteristics of the Faculty of Education and Sports Sciences. Source: Own.

\section{b. Participants}

142 first-year Early-Childhood Education and Primary-Education students have participated in the research. The vast majority of the students began their studies at 17 . This fact enhances the need to offer an institutional environment which facilitates the adaptation of the students. 
The following table profiles the participants of each degree, with students and teachers participating in the study being differentiated.

\begin{tabular}{|l|c|c|c|}
\hline & $\begin{array}{c}\text { Early-Childhood Education } \\
\text { Degree }\end{array}$ & Primary Education Degree & TOTAL \\
\hline Students & 48 & 94 & 142 \\
\hline Teachers & 3 & 3 & 6 \\
\hline TOTAL & 51 & 97 & 148 \\
\hline
\end{tabular}

Table 2. Distribution of the participants.

Source: Own.

\section{Procedure}

Given that, within the Spanish context, the use of Photovoice has been infrequent as of this date, there are few scientific publications which describe the use of said methodology and there are ever fewer which make use of it in a truly innovative fashion. In our case, the proposal originally made by Wang (1999) has been adapted to the social-contextual needs of the study.

The project started the academic year 2016-2017 with a training session on participative research and the stages of the Photovoice methodology. Said session was directed by the internal project team. In the following phases, the participating students were incorporated to represent and document the reality of their transition through images and narratives. It was conceived as a participative process based around five stages:

- Stage 1. Training the researchers (September 2016). This started with the creation of a theoretical-practical workshop on participative research and Photovoice methodology aimed at the university teachers. Next, a project plan was designed and the key questions to guide the process were agreed upon:

- General strategy: objectives, participants, and timing.

- Processing and grouping students to take the photos.

- Information-collection instruments, combining traditional strategies with digital resources.

- Issues to photograph: the taking of photographs dealing with four university topics was proposed (see Figure 1). They were invited to reflect and evaluate the places and/or situations in which they can participate, those in which they like participating, others in which they do not like participating and, lastly, those in which they cannot participate, but would like to.

Topic 1

I can participate..

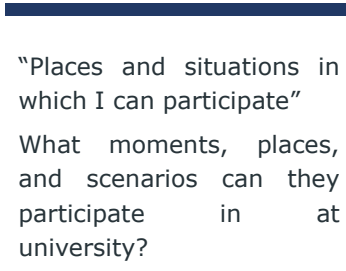

Topic 2

I like participating...

"Places and situations in which I like participating"

What scenarios create positive feelings and represent what they like about their university?
Topic 3

I don't like participating..

"Places and situations which I don't like participating in"

Which scenarios create negative feelings (fears)? What don't they like about their university?
Topic 4

I can't, but I would like to.

"Places or situations which I can't participate in, but would like to"

What are some situations they can't participate in, despite believing they could do so?

Figure 1. Topics to photograph.

Source: Own 
- Stage 2 (September 2016). Presentation and negotiation of the process with the participants. A detailed explanation of the activity was given to the first-year university students. Agreement was reached with them regarding the project plan, voluntary participation was ensured, informed consent was requested, along with the authorization to use their images.

- Stage 3. Co-researcher training (October 2016). A beginner's theoretical-practical workshop on the methodology of Photovoice and ethics and privacy issues was organized (Wang \& Redwood-Jones, 2001). This workshop also included technical-didactic training which included the following:

- Visual language and the taking of digital photographs with different instruments.

- The storage of and collaborative working with documents online.

- The use of open-source software to edit images.

- Reading and analyzing photographs.

- Creating narratives based on the visual image.

- Stage 4. Taking photographs and textualization (November 2016). The participants voluntarily formed four-member heterogeneous groups, according to their degree of digital competence. After a brief period reflecting on the research topics and the internal organization of the project, the participants freely took photographs around the faculty. Each group member took a photo of the proposed research topics and textualized it, resulting in each group collecting 16 images with their corresponding narratives referring to the spaces or situations selected. 560 images were created in total.

- Stage 5. Consensus and participative analysis by group (November 2016). Each group selected, by consensus, the four photographs (one per topic) which best reflected their vision of university life. After selecting them, as a group, the images were again cotextualized; in other words, they created a collective narrative of the photographs selected. A total of 156 photographs were finally agreed upon.

The main ICT resources used for Photovoice were digital cameras, smartphones, tablets, and phablets. To these were added secondary data derived from other strategies, such as reflexive conversation (meetings and dialogues among participants to examine aspects related to the different topics of analysis) and individual and group reflexive writing (through which the students created the narratives which explained the photographs).

A connotative analysis of the visual information was realized, provided that the images are a representation of the reality and not the reality itself. Connotative analysis is based on the subjective reading of the image, analysin what is interpretable, what it suggests to the spectator and the hidden underlying messages. This is done in this work, across the relation that is established between the images and the texts that they accompany. To do this connotative analysis a double process of codification was carried out. The first, an interpretative codification, was aimed to analyse the meaning, feelings and preferences of the students. It was a deductive one, depending on the questions: I can... (meaning, feelings and appreciations), I like... (choices), I do not like ...(choices), I would like...(wishes and needs). The second, a thematic codification, was aimed to explore the questions and topics that have been an object of reflection in the pictures (it was an inductive classification in codes, categories and subcategories: core spaces of the university life, architectural elements and material resources). Likewise, also there has been realized a denotative analysys of the visual information. The images were studied from the objective point of view of its components, with special attention being paid to the layout, framing, light, and color. 


\section{Results}

\section{a. Denotative analysis of the images}

Denotative analysis of images is based on the objective Reading of what is seen, creating a description which makes reference of the layout, framing, and color which represent the photographed reality.

\begin{tabular}{|l|l|l|l|}
\hline \multicolumn{1}{|c|}{ Layout } & \multicolumn{1}{|c|}{ Framing } & \multicolumn{1}{c|}{ Light } \\
\hline $\begin{array}{l}\text { Large general } \\
\text { descriptive layouts } \\
\text { of the space in } \\
\begin{array}{l}\text { which the action } \\
\text { takes place } \\
\text { dominated. }\end{array}\end{array}$ & $\begin{array}{l}\text { Normal and chopped } \\
\text { angles are normally } \\
\text { used to represent } \\
\text { the selected spaces } \\
\text { or objects. }\end{array}$ & $\begin{array}{l}\text { Light style: tonal, } \\
\text { monochromatic, and } \\
\text { without volume. } \\
\text { Direction of the light: } \\
\text { frontal. }\end{array}$ & $\begin{array}{l}\text { For I don't like and I } \\
\text { can't, but would like to: } \\
\text { the use of neutral and } \\
\text { cold colors to } \\
\text { emphasize the distance } \\
\text { and discomfort of the } \\
\text { participants in relation } \\
\text { to the space or object. } \\
\text { For I can and I like: the } \\
\text { use of warm colors to } \\
\text { highlight how close the } \\
\text { spectator feels to the } \\
\text { space or object. }\end{array}$ \\
\hline
\end{tabular}

Table 3. Denotative analysis of the textualized photographs.

Source: Own.

The analysis of the images themselves complemented the information provided by the university students in the text messages. As can be seen, they are not technically complex images. The students have opted for simplicity and unambiguity when taking their photographs.

\section{b. Connotative analysis.}

The textual and interpretative analysis done has allowed for the identification of three major thematic categories:

- $\quad$ Core faculty spaces (104 textualized photographs).

- Architectural elements and material resources (20 textualized photographs).

- $\quad$ Student management and participation (15 textualized photographs).

\section{b.a. Core faculty spaces}

This involves a significant number of photographs which reflect the spaces and situations which have been identified as basic in the new academic and social life which the students find themselves in. The students have identified three types of relevant spaces. These include teachinglearning spaces (49 textualized photographs), spaces specifically for students (49 textualized photographs) and, lastly a third subcategory titles "other spaces" (6 responses/textualized photographs), which include spaces which are important, but not as important as the first two categories; this includes green areas and spaces specifically for the teaching staff.

The following table shows the analysis, according to double thematic coding and interpretative analysis of the visual and textual productions found in the category 'core faculty spaces' for the students. 


\begin{tabular}{|c|c|c|c|c|c|c|c|}
\hline & \multicolumn{2}{|c|}{ Thematic coding } & \multicolumn{4}{|c|}{ Interpretative coding } & \multirow[b]{2}{*}{ TOTAL } \\
\hline \multirow{10}{*}{ 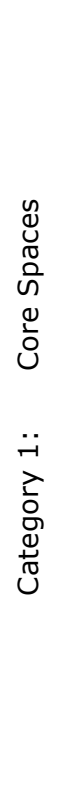 } & $\begin{array}{l}\text { Sub- } \\
\text { category }\end{array}$ & Codes & I can... & I like.... & $\begin{array}{l}\text { I don't } \\
\text { like... }\end{array}$ & $\begin{array}{c}\text { I can't, but } \\
\text { would like } \\
\text { to... }\end{array}$ & \\
\hline & \multirow{3}{*}{$\begin{array}{l}\text { Teaching- } \\
\text { learning } \\
\text { spaces }\end{array}$} & Traditional classrooms & 2 & 2 & 7 & 1 & 12 \\
\hline & & Specialized classrooms & 14 & 3 & 1 & 17 & 35 \\
\hline & & Library & 2 & - & - & - & 2 \\
\hline & \multirow{3}{*}{$\begin{array}{l}\text { Spaces } \\
\text { specifically } \\
\text { for students }\end{array}$} & Collective-work spaces & 8 & 3 & - & - & 11 \\
\hline & & $\begin{array}{l}\text { Areas for disconnection } \\
\text { and social interaction }\end{array}$ & 3 & 21 & - & 3 & 27 \\
\hline & & Student delegation & 11 & - & - & - & 11 \\
\hline & \multirow[t]{2}{*}{ Other spaces } & $\begin{array}{l}\text { Spaces for teaching } \\
\text { staff }\end{array}$ & - & - & 3 & - & 3 \\
\hline & & Green spaces & - & 3 & - & - & 3 \\
\hline & \multicolumn{2}{|r|}{ TOTAL } & 40 & 32 & 10 & 22 & 104 \\
\hline
\end{tabular}

Table 4. Core spaces for the students according to interpretative and thematic coding.

Source: Own.

Figure 2 represents the synthesis of the three sub-categories which comprise the 'core faculty spaces' category, as well as the codes found in each of them.

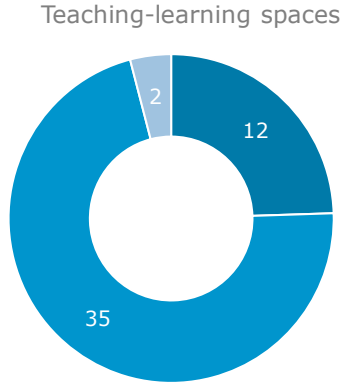

- Traditional classrooms

- Specialized classrooms

- Library

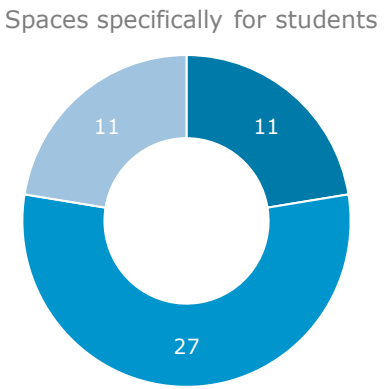

- Collective-work spaces

- Areas for disconnection and social interaction

- Student delegation

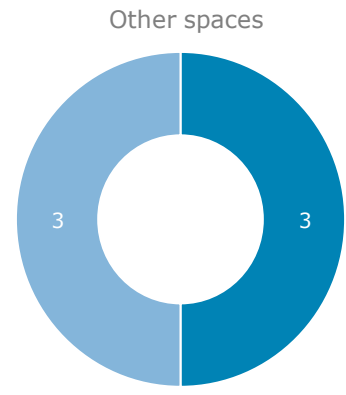

- Spaces for teaching staff

- Green spaces

Figure. 2. Core faculty spaces identified by the students. Source: Own.

The spaces designed for teaching and learning are those in which formal academic learning takes place, and represent a central pillar of university life. The students have identified three relevant spaces: traditional classrooms, specialized classrooms (for sports and music), and library.

Among their favorites are the specialized classrooms in which activities of a theoretical-practical nature take place and which, as such, favor their participation (32 photographs of sports classrooms and 3 of music classrooms). One the other hand, traditional classrooms, with tables in rows and which are normally used for master classes, receive the most criticism ( 7 out of 11 photos). These classrooms were only valued positively by 2 students. Lastly, the library, also identified as a learning space, aroused the interest of a minority of participants, who highlighted its educational value. 
Generally speaking, the photographs taken of traditional classrooms illustrate contradictory evaluations of them. Those which view them positively highlight the possibility of receiving information, learning from classmates, expressing opinions, sharing ideas, and collaborating and debating with peers. On the other hand, negative connotations associated with restrictions arising from furniture distribution, and the high number of students found in them are also made in connection with these classrooms; this limits the possibility of active and participative learning, creating negative feelings and a sense of disappointment and frustration among the students. Therefore, the lowering of the number of students per classroom, which can exceed 100, has been put forth as an essential condition for improving the dynamics, relationships, and learning methods in the classroom.

The following (figure 3), shows a sample of photographs which capture and reflect student experiences with regards to traditional university classrooms.

I can participate.

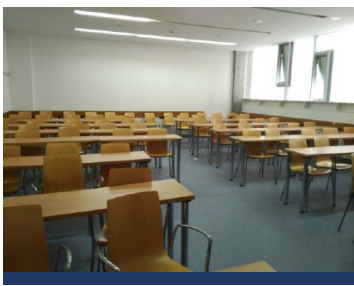

"Receive information provide ideas, interact with professors and other students, receiving help and learn from classmates. We can participate in class, but we don't like to given the large number of students

in the classrooms; this

makes participation and

makes participation and

between the students and

the professor difficult"
I like participating...

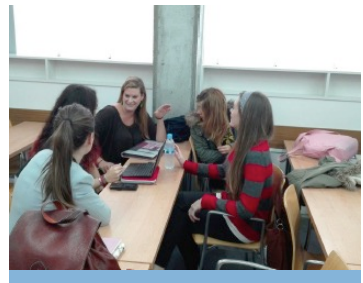

"Express our opinions, help other students, learn from others, share knowledge and ideas, and engage in participatory debates in the classroom"
I don't like participating...

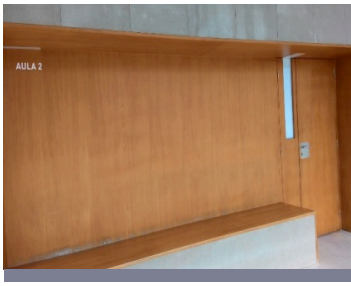

"This is our classroom. Fears and worries pop up, we sometimes get we sometimes get times we get annoyed disappointed, or stressed.. we don't like this place a lot"
I can't, but I would like to...

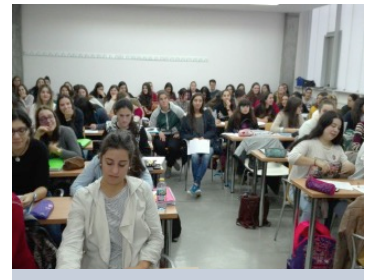

"Talk about and express doubts, but sheer number of students makes this impossible for me. Many classmates take on a classmates take on a
passive role, which is a problem because it limits their experience

Figure. 3. Spaces meant for the teaching-learning process: Traditional classrooms. Source: Own

The second group of relevant teaching-learning spaces, specialized classrooms, receive greater support from the students (see figure 4). They especially value the building's sports facilities and the possibility of using them for social interaction and for learning sports-based values. As an exception, only one student pointed out the competitiveness inherent in some sports or sports spaces. Students are also in agreement on the need to demand the ability to more freely use certain spaces whose access is contingent on the presence of professionals or monitors. 
I can participate...

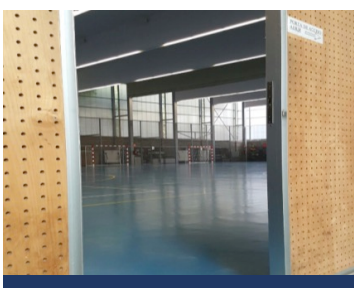

"Using some of the building's sports facilities. It's an impressive space, which makes our university unique"
I like participating...

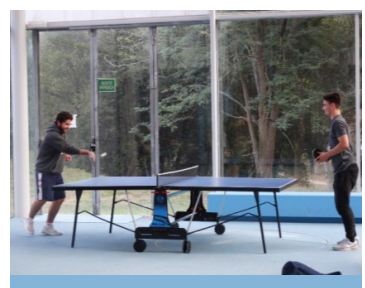

"You can make friends and meet new people, which promotes fellowship and cohesion"
I don't like participating...

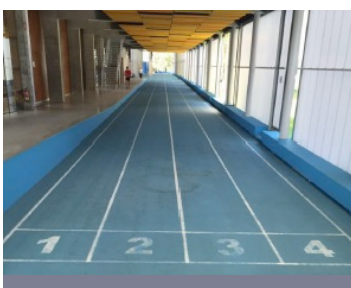

"It is a competitive space in which 'the best' stands out. It doesn't have a relaxed and casual atmosphere"
I can't, but I would like to...

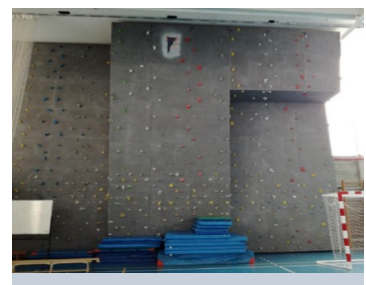

"Using some of the specialized equipment such as the climbing wall, docks, or trampolines. We understand they present a risk and require professional supervision"

Figure. 4. Spaces meant for the teaching-learning process: Specialized classrooms.

Source: Own

The subcategory "spaces specifically for students" refers to places for the students' own use. These spaces are generally viewed in a positive light by students. They especially point out open, common areas, with furniture for working and relaxing (mobile tables and chairs) in the building's wide corridors. They are appreciated for their versatility and functionality, with special mention being made of didactic possibilities, for group work, collaboration, and developing a sense of community. Other spaces which are equally valued for the aesthetics and functionality are those meant to facilitate rest and social interaction. The students have pointed out the possibility of using these spaces to disconnect, talk, enjoy relaxing moments, etc.

Lastly, the value given to formal spaces for student representation, participation, and decisionmaking is considerable, such as the assemblies and Student Delegation. Recognizing their ability to opine on and influence the student dynamic is one of the issues they emphasize the most with regards to their new university life.

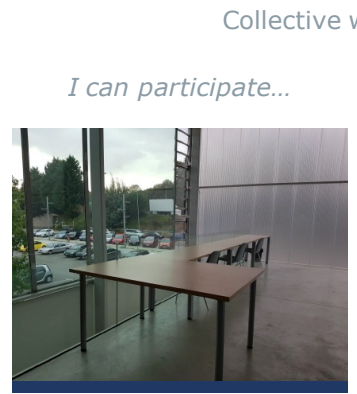

"This is a versatile space which is available to us. We especially like its large windows and sense of calm"

Spaces for disconnecting and social interaction

I can participate...

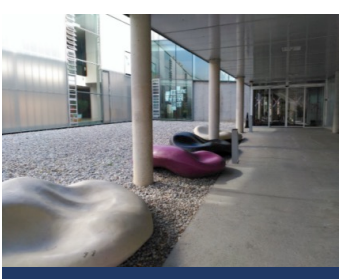

"It is a very important, and necessary, place to meet and socialize. The aesthetic is also original and informal, which is different from other universities"
I like participating..

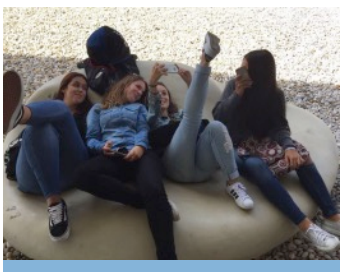

"We like relaxing, connecting with students from other degrees, and speaking in a relaxed atmosphere" 
I can participate..

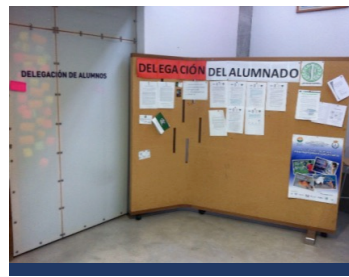

"Exercising our voice and our vote at the Student Assemblies, which is the top body for participation and collective decisionmaking by students; it's marvelous"
I like participating..

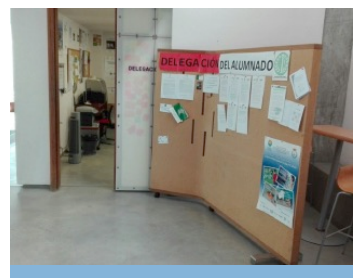

"It's a space made designed for and by students in order to help them at any moment and in any situation"

Figure 5. Spaces specifically for students: collective spaces, rest areas, and Student Delegation.

Source: Own.

The last group of photographs has been included in the sub-category "other spaces" (figure 6). In them, situations and spaces such as teachers' offices and green areas are commented on. The offices are, generally speaking, given poor marks both as a result of their physical characteristics (small, narrow, and poorly lit, in contrast with the open common spaces), and, above all, because of the vertical relationship and authority which the new students attribute to the teaching staff. On the other hand, the students perceive and highly value the commitment made by the faculty with regards to the environment and sustainability. The green areas, the building's large windows, which open onto natural surroundings, and the interior design based around plants all receive a very positive grade from the students.

I like participating...

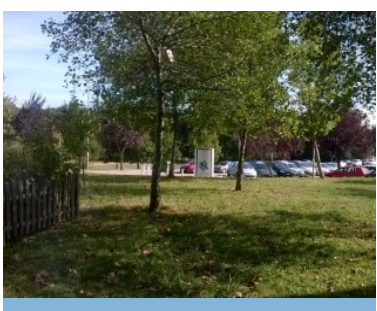

"We like having green areas on campus; it makes us feel happy and free when leaving class. Natural surroundings are great for freeing the mind and providing fresh air"

\section{I don't like participating...}

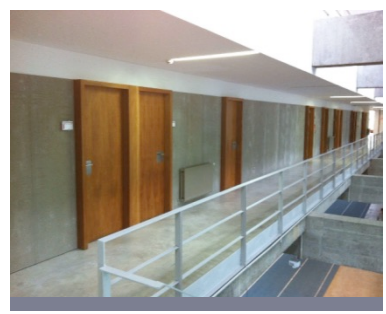

"The teachers' offices give off a cold vibe, due to their appearance and the little traffic which passes through them. We have a very negative opinion of them; nobody likes going because they make us fee nervous and uncomfortable"

Figure 6. Spaces specifically for students: other spaces.

Source: Own.

\section{b.b. Architectural elements and material resources}

All valuations which the participants (table 5) have given to the building's fixed elements, material resources (tangible items available to students), and toilets are negative. A clear 'I don't like' or I can't, but would like to' (20 textualized photographs) have been assigned to certain architectural elements, such as the windows or the building's exit. Regarding material resources, they express 
their disapproval of the classroom furniture they use daily, especially the tables and chairs, because of its lack of functionality and comfort (Figure 7).

\begin{tabular}{|l|l|c|c|c|c|c|}
\hline \multicolumn{2}{|c|}{ Thematic coding } & \multicolumn{3}{c|}{ Interpretative coding } \\
\hline \multicolumn{1}{|c|}{ Category } & \multicolumn{1}{|c|}{ Codes } & I can... & I like.... & $\begin{array}{c}\text { I don't } \\
\text { like... }\end{array}$ & $\begin{array}{c}\text { I can't, but } \\
\text { would like } \\
\text { to... }\end{array}$ & TOTAL \\
\hline $\begin{array}{l}\text { Architectural } \\
\text { elements and } \\
\text { material resources }\end{array}$ & $\begin{array}{l}\text { Furniture and material } \\
\text { resources }\end{array}$ & - & - & 11 & 2 & 13 \\
\cline { 2 - 7 } & Restrooms & - & - & 5 & 2 & 7 \\
\hline
\end{tabular}

Table 5. Core spaces for students according to interpretative and thematic coding Source: Own

I don't like participating..

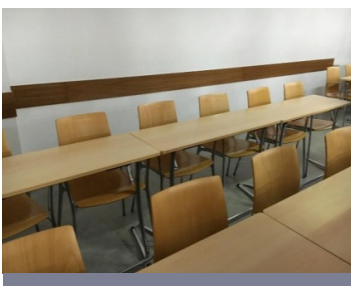

"The furniture is not adapted to student needs in terms of size or comfort"
I don't like participating...

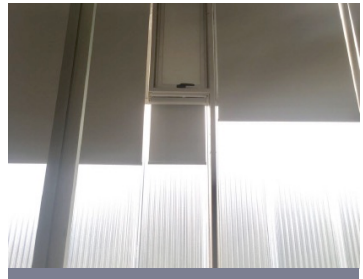

"The classroom windows are very high up, are small, don't air the class, and don't allow in enough natural light to meet our natural light to meet our needs"
I can't, but I would like to...

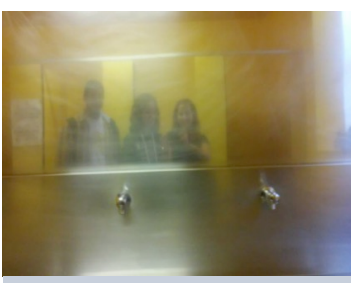

"There are opaque mirrors which don't do what they're meant to do. We believe they are necessary
I can't, but I would like to...

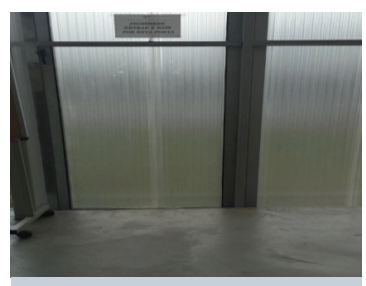

"The center only has one exit. There needs to be more options because we have to cross the entire place to be able to rest between classes"

Figure 7. Textualized participative photographs of architectural elements and material resources Source: Own

In the photographs which exemplify the feeling and opinion of the students regarding the building's structure, special attention has been made of the low degree of functionality found in the classrooms as a result of hardly having any natural light (small and opaque windows), as well as problems arising from only one of the four doors being available for both entering and exiting, which makes moving around more difficult.

Likewise, the furniture and its arrangement in the classroom, does not facilitate group work and makes other more creative or participative uses more difficult. The tables and chairs are modern in design, but are very heavy and difficult to handle; this greatly affects the relationship between students and teachers and determines the teaching methodology. Another example of facilities which are not adapted to student needs are the restrooms.

\section{b.c. Student management and participation}

Lastly, the demands made by some of these young students, since their recent entry into university, to participate should be highlighted. There are two different areas of participation and decision-making in which they would like to have a greater voice and play a larger role. Firstly, they would like to be involved in academic decision-making, on issues such as models as evaluation instruments; they propose a more practical, and less academic, approach. Secondly, 
they wish to contribute to and be heard on organizational issues such as the creation of class schedules, the ongoing recycling policy for the faculty or the offer of services available to the university community in the building. They have proposed, for example, the inclusion of a photocopying service in the center itself.

Table 6 is a grouping of the responses dealing with their coding and figure 8 provides a sample of textualized photographs dealing with this category.

\begin{tabular}{|c|c|c|c|c|c|c|}
\hline \multirow{2}{*}{ Thematic coding } & \multicolumn{4}{c|}{ Interpretative coding } & \\
\hline \multirow{2}{*}{ Category } & Codes & I can... & I like.... & $\begin{array}{c}\text { I don't } \\
\text { like... }\end{array}$ & $\begin{array}{c}\text { I can't, but I } \\
\text { would like to... }\end{array}$ & TOTAL \\
\hline $\begin{array}{c}\text { Student } \\
\text { management and } \\
\text { participation }\end{array}$ & Academic decisions & - & - & 2 & - & 2 \\
\cline { 2 - 7 } & Organizational decisions & 2 & 1 & - & 10 & 13 \\
\hline
\end{tabular}

Table 6. Research topics related to services and other issues

Source: Own

I can participate.

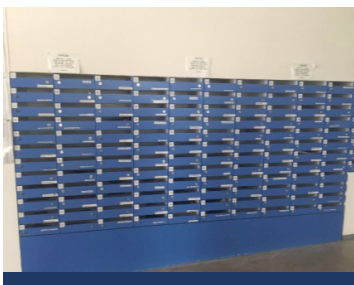

"There are mailboxes for students to put suggestions, complaints, and claims in to improve service"
I like participating.

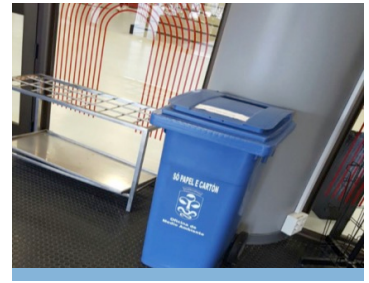

"The university should get us involved in recycling. We are promoting awareness and ensuring that materials are reused"
I don't like participating...

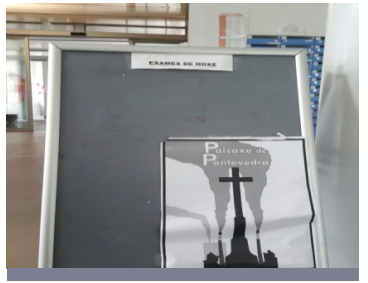

"Exam participation. We think there are other evaluation systems which above all those focused on hands-on experience"
I can't, but I would like to...

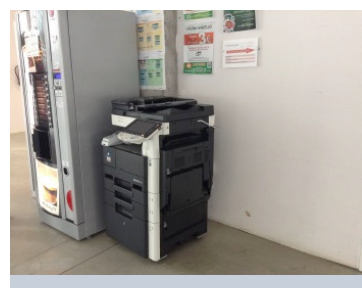

"The university itself should have a copying service where you can print all necessary material"

Figure 8. Textualized photographs in the Student Participation category. Source: Own.

\section{Conclusions}

Below are the conclusions of the study, connected with its aims.

\section{a. The value of visual-narrative approaches as an evaluation strategy}

The research carried out has allowed us to enter a field of study with narrative and visual methodological strategies in order to evaluate the transition to university from the perspective of first-year students. This study confirms the suitability of their incorporation within the evaluation framework.

Visual and narrative methodologies have demonstrated other ways of producing evaluative data in which both approaches are integrated and are mutually complementary. This work agrees with Spencer (2011), in that the idea of the visual and narrative, can be evaluated as a creative, accessible, and authentic complement to the usual evaluations. The visual narratives can become a very valuable resource for studying feelings, motivations, and goals; these are difficult to record 
with traditional evaluation strategies. This has provided momentum to evaluative research, since it has allowed for "an intensive approach regarding the aforementioned aspects, which are difficult to perceive with the use of closed questions (questionnaires), and the logic of statistical representation" (Yañez-Urbina, Figueroa, Soto and Sciolla, 2018, p.15).

Likewise, narrative and visual methods can play an important role in evaluating student perceptions and needs (Manay \& Wilcok, 2015) since images and technological resources are omnipresent in the lives of today's university students. Photovoice is one of these very valuable visual-narrative research strategies to make reflective practice and self-exploration possible. Furthermore, it can be particularly useful for analyzing questions of a significantly personal nature, such as how students situate themselves within the new culture and the various educational scenarios found at university.

In addition to this, we believe that Photovoice, as a visual study based on the photographs taken by the participants, enriched by the narrations of their experiences, generated a better understanding of their personal reality (Meredith \& Roanne, 2014) on the recent university life. In short, using photography to collect data allows one to have visual evidence of evaluations made by students when arriving at university: taking photos of those places which make participation difficult or easy; discovering the use of different electronic devices; learning about digitalphotography software; using techniques specific to this field (framing, light, tone, etc.); learning how to view a photograph, how to retouch it, etc. We shouldn't forget that the most relevant aspect of image is that which its creator intends to transmit (Gillian, 2015). With regards to written evidence, the photo texts include opinions, feelings, and interpretations. This data represents enormously valuable information for 'reading' how students feel about and evaluate their new situation at university, in order to give meaning to their university experience. It confirms that both representative forms (visual and textual) can give context to meaning (Purcell, 2015).

In short, student visual-narrative documentation allows one to view Photovoice as a participative inquiry proposal, and a resource for understanding, problematizing, and evaluating certain aspects of university life. Students in this study have actively created and analyzed images in order to represent university life as they live it, through photos and text. This therefore represents both an emotional reflection and critical evaluation of their first university experiences.

\section{b. Meanings and needs of the students regarding the university through Photovoice}

This research is contextualized in an institution which, architecturally speaking, is a unique building, both in terms of design and construction materials. This fact, as we have seen, clearly affects academic and social life.

The first-person narratives of the students provided by the photos represent materials which map and problematize the new university environment, pedagogical work, and the role they wish to take on for themselves. This makes them highly important documentary materials, which induce reflection, interpretation, exchange, and horizontal discussion among the students.

The perception of first-year university students of the institutional environment they are arriving at, expressed via Photovoice, is fundamentally focused on the spaces which make up their university surroundings. This is why surroundings specific to teaching-learning (classrooms) and those exclusively for student use are core:

Regarding the classrooms, students note positively that active teaching-learning methods are used. Teaching, according to the students, is not done in a passive manner, with only lecturers intervening. This way of doing things, however, makes 
them feel anxious and uncertain due to the processes and responsibilities associated with active learning being more complex.

- $\quad$ At the same time, students complain about classrooms being overcrowded and limited in terms of space, which dampens active participation, as well as interaction and communication during class sessions. The students agree, therefore, with the idea that the availability of space and resources determines the design of the surroundings and results in more constructive and affirmative learning strategies for developing student competences (Espinoza \& Rodríguez, 2017).

- With regards to facilities, students believe it is important to pay attention to their rooms and material resources. They prefer those spaces meant for social interaction and sports, such as the resting areas distributed throughout the building in the common areas. This evaluation of the university's adequacy is in line with that argued by Espinoza \& Rodríguez (2017), who argue that, for young people, "not having neither facilities nor programs which promote sports and co-existence can be counterproductive in the formation and establishment of assertive habits and the prevention of risky behavior" (p.13).

- $\quad$ Another of the core spaces identified by students are those exclusively for their use and enjoyment; these are especially valued because their design and equipment make it possible to transform and adapt them to meet student needs. The participants especially value those spaces created for rest and social interaction, places which allow them to interact and build relationships among peers. Although, to a lesser degree, they also appreciate there is a wide range of spaces for group-work available to them.

Regarding the building's architectural elements, student opinion is negative, generally speaking. They point out the windows do not adequate natural light or ventilation, which makes them uncomfortable. They also point to there only being one exit in use, that the bathroom mirrors do not reflect, and that the furniture is scarcely adapted to their needs.

In short, the degree to which the Faculty has adequate facilities, spaces for sports, classroom resources and active methodologies determines the ease at which first-year students are incorporated and actively participate. This evaluation of core spaces as key makes it clear that facilities, infrastructure and materials intercede and help to create a motivating, stimulating, and enriching educational environment, which promotes the learning process; this is in line with studies done by Tse, Daniels, Stables \& Cox (2018).

\section{c. Student participation in an institutional context}

By reflecting, students have developed their identities as such; they view themselves as subjects of university education with agency for active participation, and not only as objects of academic training. What they believe it means to be a student is unquestionably linked to participation processes which are very different from classical approaches which view students as the recipients and receptors of the educational process (Fielding, 2011).

When students talk to us about their university experience, they do not hesitate to mention their participation in management bodies and academic questions; they bring concrete ideas with regards to topics such as knowledge evaluation, Schedule distribution, etc. They ask that they be recognized as competent agents and active subjects (Bragg, 2007) in the management of pedagogical and institutional spaces. Without a doubt, an institution focused on the needs of its users is only possible if they lead the way.

They also appreciate, in particular, being able to democratically participate, via voice and vote, through student-representation bodies, as is the case with the student delegation. There they meet and create a space for debate and constructive dialogue in relation to their preoccupations and how to be a university student and continuously create a university. 
We end with the words accompanying a picture of a young student, which reflect a common feeling among this study's participants about the university they would like to have:

"A place of participation, where you share your ideas and knowledge. This place and time will undoubtedly be remembered in the future for their incredible moments and the positive emotions that go along with meeting people and learning".

\section{d. Contributions and project limitations}

The most substantive of this project's contributions are three in number. The first one is the recognition of the visual-narrative methodology as an evaluation strategy; the second one is the suitability of Photovoice as a participative research strategy, capable promoting reflection and the questioning of student life; the third is the recognition of students having the agency to participate in and improve the university.

With regards to the limitations of the research carried out, solely focusing on the students' perspective can be pointed to. In order to be able to fully evaluate university access, a more inclusive evaluation would be ideal; this would mean listening to the voices of the other members of the university community, such as teachers, the executive team, as well as administrative and service personnel. Another limitation of the project is that it only studied the transition at a specific moment, that of arriving at university. Follow-up research has not been carried out to see if the students' initial meanings remained the same or changed over the course of their first year at university.

\section{Acknowledgments}

This article would not have been possible without the participation of the students, whose engagement we wish to thank. The department has also played an important part in supporting the development of this study. Lastly, this project has been financed by the EDU2015-68617-C4-1-R Project, "Innovation Networks for Educational and Social Inclusion", (Dir. A. Parrilla) financed by the Spanish Ministry of Economy and Competitiveness.

\section{References}

Allen, Q.. (2012, august). Photographs and stories: ethics, benefits and dilemmas of using participant photography with black middle-class male youth. Qualitative Research, 12(4), 443-458.

Bragg, S.. (2007, october). "Student voice" and governmentality: the production of enterprising subjects? Discourse: studies in the cultural politics of education, 28(3), 343-358.

Bukowski, K.. \& Buetow, S.. (2011, march). Making the invisible visible: A photovoice exploration of homeless women's health and lives in central Auckland. Social Science and Medicine, 72(5), 739-746.

Cebrián, M.., Serrano, J.. \& Ruiz, M.. (2014, october). eRubrics in Cooperative Assessment of Learning at University. [Las eRúbricas en la evaluación cooperativa del aprendizaje en la Universidad]. Comunicar, $43,153-161$.

Corominas, E.. (2001, january). La transición a los estudios universitarios. Abandono o cambio en el primer año de Universidad. Revista de Investigación Educativa, 19(1), 127-151.

Cortés-Selva, L.. \& Wandosell-Fernández de Bobadilla, G.. (2018, july). Improving university students' results: a client-based experiment through design thinking and visual storytelling in communication. Educación $X X 1,21(2), 205-224$.

Delgado, M.. (2015). Urban youth and photovoice: Visual ethnography in action. New York: Oxford University Press.

Doval, M.I.., Martínez-Figueira, M.E.. \& Raposo, M.. (2013, december ). La voz de sus ojos: la participación de los escolares mediante Fotovoz. Revista de Investigación en Educación, 11(3), 150-171. 
Edwards, M.., Perry, B.., Janzen, K.., \& Menzies, C.. (2012, march). Using the artistic pedagogical technology of photovoice to promote interaction in the online post-secondary classroom: The students' perspective. Electronic Journal of e-Learning, 10(1), 32-43.

Espinoza Núñez, L.A.. \& Rodríguez Zamora, R.. (2017, january). La generación de ambientes de aprendizaje: un análisis de la percepción juvenil. RIDE. Revista Iberoamericana para la Investigación y el Desarrollo Educativo, 7(14), 110-132.

Esteve, F.., Duch, J.. \& Gisbert M.. (2014). Los aprendices digitales en la literatura científica: diseño y aplicación de una revisión sistemática entre 2001 y 2010. Pixel-Bit Revista de Medios y Educación, 45, 9-21.

Fielding, M.. (2011, april). La voz del alumnado y la inclusión educativa: una aproximación democrática radical para el aprendizaje intergeneracional. Revista Interuniversitaria de Formación del profesorado, 25(1), 31-61.

Figuera Gazo, P.. \& Coiduras Rodríguez, J.L.. (2013, september). La transición a la universidad: un análisis desde la diversidad de las voces de los estudiantes. Revista de Educación, 362, 713-736.

Freire, P.. (1970). Pedagogía del Oprimido. Montevideo: Tierra Nueva.

Garner, S.L.. (2014, october). Photovoice as a teaching and learning strategy for undergraduate nursing students. Nurse Education Today, 34(10), 1271-1274.

Gascón, F.. \& Godoy, L.. (2015, july). Presencia e in-diferencia. Por un estatuto visual de la niñez. Revista Latinoamericana de Ciencias Sociales, Niñez y Juventud, 13(2), 645-656.

Gallego-Arrufat, M.., \& Cebrián-de-la-Serna, M.. (2018, october). Contribuciones de las tecnologías para la evaluación formativa en el prácticum. Profesorado, Revista de Currículum y Formación del Profesorado, 22(3), 139-161.

Gillian, R.. (2015). Visual methodologies: An introduction to researching with visual materials. London: Sage.

Johnston, B.. (2013). El primer año de universidad: una experiencia positiva de transición. Madrid: Narcea.

Johnson, G.A.. (2011, november). A child's right to participation: Photovoice as methodology for documenting the experiences of children living in kenyan orphanages. Visual Anthropology Review, 27(2), 141-161.

Kaplan, I.. \& Howes, A.. (2004, october). 'Seeing Through Different Eyes': exploring the value of participative research using images in schools. Cambridge Journal of Education, 34(2), 143- 155.

Mannay, D.. (2017). Métodos visuales, narrativos y creativos en investigación cualitativa. Madrid: Narcea.

Mannay, D.. \& Wilcock, C.. (2015, march). What students want? Exploring the role of the institution in supporting successful learning journeys in online distance education. Widening Participation and Lifelong Learning, 17(1), 49-63.

Mitchell, C.. (2011). Doing Visual Research. Sage: London.

Meridith B.. \& Roanne T.. (2014, january). "I just don't think there's any other image that tells the story like [this] picture does": Researcher and participant reflections on the use of participant-employed photography in social research. International Journal of Qualitative Methods, 13(1), 185-205.

Messiou, K.. (2013, december). El compromiso con la voz del alumnado: uso de un marco de trabajo para abordar la marginación en las escuelas. Revista de Investigación en Educación, 11(3), 97-108.

Nelson, E.. \& Christensen K.. (2009, december). Photovoice in the middle: How our students experience learning at school and beyond. New Zealand Journal of Teachers' Work, 6(1), 35-46.

Nieto, J.M.. \& Portela, A.. (2008, december). La inclusión de la voz del alumnado en el asesoramiento para la mejora de las prácticas educativas. Profesorado. Revista de currículum y formación del profesorado, 12(1), 1-26.

Novek, S.., \& Morris-Oswald, T.. (2012, april). Using photovoice with older adults: some methodological strengths and issues. Ageing \& Society, 32(Part 3), 451-470.

Parrilla, Á..., Martínez-Figueira, M.E... \& Zabalza-Cerdeiriña, M.A.. (2012, september). Diálogos infantiles en torno a la diversidad y la mejora escolar. Revista de educación, 359, 120-142.

Parrilla, A.., Raposo-Rivas, M.., Martínez-Figueira, M.E.. \& Doval, M.I.. (2017, november). Materiales didácticos para todos: el carácter inclusivo de fotovoz. Revista Educatio Siglo XXI, 35(3), 17-38.

Prins, E.. (2010). Participatory photography: A tool for empowerment or surveillance? Action Research, 8(4), 426-443.

Purcell, N.. (2015). De la caza del objeto al movimiento en la imagen: reflexiones sobre las posibilidades y límites de la cámara fílmica y fotográfica en la investigación social. Tesis Doctoral. Universidad Autónoma de Barcelona. 
Redecker, C.. (2013). The Use of ICT for the Assessment of Key Competences. Spain: Luxembourg: Publications Office of the European Union. Scientific and Policy Report by the Joint Research Centre of the European Commission. Retrieved from http://ftp.jrc.es/EURdoc/JRC76971.pdf

Rudduck, J.. \& Flutter, J.. (2007). Cómo mejorar tu centro escolar dando la voz al alumnado. Madrid: Morata.

Smith, L.., Bratini, L.. \& Appio, L.M.. (2012, january). "Everybody's teaching and everybody's learning": Photovoice and youth counseling. Journal of Counseling \& Development, 90(1), 3- 12.

Spencer, S.. (2011). Visual research methods in the social science: awakening visions. London: Routledge.

Susinos, T.. (2012, september). Presentación. Las posibilidades de la voz del alumnado para el cambio y la mejora educativa. Revista de Educación, (359), 16-23.

Tur, G.. \& Urbina, S.. (2014, december). Blogs as Eportfolio Platforms in Teacher Education: Affordances and Limitations Derived from Student Teachers' Perceptions and Performance on their Eportfolios. Digital Education Review, 26, 1-23.

Tse, H.M.., Daniels, H.., Stables, A.. \& Cox, S.. (2018). Designing Buildings for the Future of Schooling Contemporary Visions for Education. Londres: Routledge.

Wang, C.C.. (1999). Photovoice: A participatory action research strategy applied to women's health. Journal of Women's Health, 8(2), 185-192.

Wang, C.C.. \& Redwood-Jones, Y.A.. (2001, october). Photovoice ethics: Perspectives from Flint photovoice. Health Education \& Behavior, 28(5), 560-572.

Wang, C.C.. (2006, october). Youth participation in photovoice as a strategy for community change. Journal of Community Practice, 14(1-2), 147-161.

Wang, C.. \& Burris, M.. (1997, june). Photovoice: concept, methodology, and use for participatory needs assessment. Health Education \& Behavior, 24(3), 369-387.

Yañez-Urbina, C.., Figueroa, I.., Soto, J.. \& Sciolla, B.. (2018, july). La voz en la mirada: Fotovoz como una metodología para explorar los procesos de inclusión-exclusión desde la perspectiva del estudiantado. Pensamiento Educativo. Revista de Investigación Educacional Latinoamericana, 55(2), 1-16.

Zenkov, K.. \& Harmon, J.. (2009, april). Picturing a writing process: Photovoice and teaching writing to urban youth. Journal of Adolescent \& Adult Literacy, 52(7), 575-584. 